\title{
Kryzysowe macierzyństwo - młode matki w systemie opieki instytucjonalnej
}

\begin{abstract}
Abstrakt
Celem artykułu jest przybliżenie czytelnikowi kwestii związanych z wczesnym macierzyństwem, w szczególności jednak zaprezentowana jest grupa dziewcząt przebywających w placówkach opiekuńczo-wychowawczych i resocjalizacyjnych, które będąc nastolatkami, zachodzą w ciążę i rodzą dzieci. Ukazany zostanie wymiar prawny i społeczny tego zagadnienia, a także poruszone kwestie stanowiące obecnie największe wyzwanie zarówno dla ustawodawcy, jak i dla społeczeństwa. Autorka skoncentruje się na zagadnieniu rozdzielania matki i dziecka, jego konsekwencjach i możliwościach jego uniknięcia. Tekst opierać się będzie częściowo również na doświadczeniu Fundacji po DRUGIE, która od 8 lat wspiera młode osoby w kryzysie, również nastoletnie matki, a także realizuje projekt budowy ośrodka dla młodych matek i ich dzieci, w którym będą poddawane oddziaływaniom mającym na celu ich pozytywną readaptację społeczną.
\end{abstract}

Słowa kluczowe: nastolatki, przedwczesne macierzyństwo, matka, kryzys.

\section{Motherhood in Crisis - Young Mothers in the Institutional Care System}

\begin{abstract}
The aim of the article is to familiarize the reader with issues related to early motherhood; in particular, the paper presents a group of girls staying in education and resocialization centers who, as teenagers, became pregnant and had babies. The legal and social dimension of this issue will be presented as well as issues that are currently the greatest challenge for both the legislator and society. The author will focus primarily on the issue of separating the mother and the child, its consequences,
\end{abstract}

\footnotetext{
* Uniwersytet Warszawski, Instytut Prawa Karnego.
} 
and the possibilities for avoidance. The text will be based in part on the experience of the Po DRUGIE Foundation, which for 8 years has been supporting young people in crisis, including teenage mothers, and is running a project of building a center for young mothers and their children, where they will learn how to be a part of a family and society.

Keywords: teenagers, early motherhood, mother, crisis.

\section{Wprowadzenie}

Macierzyństwo czy rodzicielstwo należy do kanonu norm społeczno-obyczajowych. O tym bowiem, kiedy kobiety decydują się być matkami, bardzo często decyduje nie sama biologia, ale właśnie pewien zestaw reguł wypracowany w danym społeczeństwie. W starożytnej Grecji czy Rzymie wczesne małżeństwa należały do zwyczaju, którego rezultatem było również podejmowanie aktywności seksualnej w wieku 12-14 lat (Żelazkowska 2016). Bezdzietne dwudziestokilkuletnie kobiety były rzadkością i uważano, że są bezpłodne. Obecnie, mimo obniżającego się wieku inicjacji seksualnej (Izdebski 2011; Raport... 2012), kobiety znacznie później niż kiedyś decydują się na posiadanie potomstwa, a za odsuwaniem tej decyzji w czasie stoi kilka powodów. Przede wszystkim oczywiście wpływ na to ma ogromny postęp w zakresie medycyny i farmakologii, który umożliwił kontrolowanie płodności. Są jednak inne aspekty, które mają równie istotne znaczenie, takie jak chociażby podniesienie świadomości społecznej w zakresie zagrożeń wynikających z przedwczesnego macierzyństwa, ale także i powszechniejszy dostęp do wiedzy naukowej z tego zakresu, pojawianie się ustawodawstw krajowych i międzynarodowych gwarantujących ochronę praw dziecka i nakładających na państwa obowiązki podejmowania konkretnych działań, czy nawet szybki rozwój gospodarczy. Nie oznacza to jednak, że we współczesnej polskiej rzeczywistości nastolatki nie rodzą dzieci. W zależności od źródła podaje się, że ciąże nastoletnich dziewcząt stanowią około 3,4-8\% wszystkich ciąż (Wróblewska 2006; Szukalski 2010). Choć odsetek ten się zmniejsza, to nadal w 2017 r. ponad 10 tys. dziewcząt poniżej 20. roku życia zostało matkami (Rocznik Demograficzny 2018: 296). Dane Głównego Urzędu Statystycznego za rok 2018 wskazują, że takich dziewcząt było ponad 9 tys., z czego 2114 przypadków dotyczyło nastolatek w wieku 17 lat lub mniej (GUS 2018). Każda taka ciąża może stanowić ogromne wyzwanie nie tylko dla zdrowia i życia kobiety, gdyż jak powszechnie wiadomo, im młodsza jest przyszła matka, tym większe ryzyko powikłań, ale także generować problemy prawne, społeczne, ekonomiczne, jak również psychologiczne.

Szczególną podgrupę stanowią młode dziewczęta, znajdujące się w systemie opieki instytucjonalnej, w placówkach opiekuńczo-wychowawczych czy resocjalizacyjnych. Ze względu bowiem na ich specyficzną sytuację zarówno prawną, jak i społeczną pojawiać się mogą dodatkowe zagrożenia, których rezultatem może być 
naruszenie podstawowych przedmiotów ochrony prawnej, jakimi są dobro dziecka i macierzyństwo. Przedstawienie zagadnienia wczesnego macierzyństwa właśnie z perspektywy dziewcząt przebywających pod opieką państwa jest głównym, choć nie jedynym celem tego artykułu. Próba przyjrzenia się warunkom społecznym, w jakich młode kobiety stają się matkami, a także istniejącym regulacjom prawnym pomoże $\mathrm{w}$ zaprezentowaniu podstawowych trudności, $\mathrm{z}$ jakimi zmagamy się jako państwo, społeczeństwo czy ustawodawca i w rezultacie pozwoli na sformułowanie wniosków de lege ferenda służących poprawie sytuacji prawno-społecznej nastoletnich matek w Polsce.

\section{Ciąże nastolatek}

W literaturze przedmiotu spotkać można wiele rozbieżności terminologicznych, które utrudniają zrozumienie zagadnienia ciąż nastolatek. Na wstępie należy więc zaprezentować definicje, które najczęściej pojawiają się przy opracowywaniu tego tematu. „Nastolatka” jest terminem obejmującym dziewczęta w wieku od 11 do 19 lat. Innym pojęciem jest „osoba małoletnia”, bowiem zgodnie z definicją zawartą w kodeksie cywilnym (Dz.U. z 2018 r., poz. 1025) oznacza osobę, która nie ukończyła 18. roku życia (lub nie zawarła wcześniej małżeństwa). W tej grupie będą się więc mieścić tylko te dziewczęta, które urodziły dziecko przed ukończeniem 18. roku życia. Natomiast termin „osoba nieletnia”, mający najbardziej skomplikowane rozwinięcie, oznacza dziecko między 13. a 17. rokiem życia, które popełniło czyn karalny, osobę do lat 18, której zachowanie wskazuje na demoralizację lub też osobę do 21. roku życia, jeśli w wyniku postanowienia sądu opiekuńczego została umieszczona w placówce resocjalizacyjnej (Dz.U. z 2018 r., poz. 969), w polskich realiach - w zakładzie poprawczym.

Należy wskazać, że podgrupą, której sytuacja jest najbardziej skomplikowana, są małoletnie dziewczęta objęte opieką instytucjonalną, czyli przebywające w placówkach opiekuńczo-wychowawczych i resocjalizacyjnych. Są to te dziewczęta, które przed ukończeniem 18. roku życia rodzą dzieci, a ze względu na fakt pozostawania poza rodziną biologiczną czy prawną, a także ze względu na istniejące regulacje ustawowe zmuszone są mierzyć się nie tylko z wyzwaniami dnia codziennego, ale także z długofalowymi skutkami braku adekwatnej polityki prorodzinnej, obejmującej swoim działaniem również młode matki. Ich perspektywa, w zakresie tego opracowania, jest najistotniejsza.

Szacuje się, że około 6-18\% nastolatek w wieku 15-19 lat na całym świecie każdego roku zostaje matkami (Mikołajczyk-Lerman 2007; Napieralska 2010). W Polsce odsetek ten jest oczywiście niższy, a jak wskazują statystyki, liczba dzieci urodzonych przez bardzo młode dziewczęta spada, jednak biorąc pod uwage analizę wieloczynnikową tego zjawiska, dane są niezmiennie niepokojące. W $2003 \mathrm{r}$. 11097 dziewcząt w wieku 13-18 lat zostało matkami, z czego 637 przypadków 
dotyczyło już co najmniej drugiego porodu. W 2014 r. odnotowano tylko (sic!) 7241 porodów w tej grupie, z czego 429 było związane z porodem co najmniej drugiego dziecka (Kempińska 2017: 58-59). Najmłodsze matki miały 13 lat i było ich kolejno 5 i $10 \mathrm{w}$ prezentowanych latach. W każdym z tych zestawień są 15-latki, które zostają matkami po raz drugi (odpowiednio 12 i 3 przypadki). Biorąc pod uwagę chociażby ryzyko dla zdrowia i życia tych dziewcząt (Bień i in. 2015: 125-131), każdy taki przypadek powinien stanowić motywację do głębszej analizy tego zjawiska i wprowadzenia realnych i skutecznych metod przeciwdziałania jego występowaniu.

Czynnikiem, który ma ogromne znaczenie dla omawianej tematyki, jest wiek inicjacji seksualnej, który zależeć może od wielu zmiennych, takich jak przykładowo kraj zamieszkania, kultura czy tradycja. W literaturze podkreśla się, że współcześnie inicjacja często wyprzedza pojawienie się potrzeb seksualnych (Kempińska 2017: 33; Obuchowska, Jaczewski 2002), a jej wczesne występowanie świadczy o instrumentalnym podejściu do kwestii cielesności człowieka (Imieliński 1992). Badania HBSC (Health Behaviour in School-aged Children) z 2009-2010 r. wskazują, że w Polsce 13\% dziewcząt i 19\% chłopców w wieku 15 lat jest już aktywna seksualnie (Currie i in. 2012), a w badaniu z lat 2013-2014 odsetek ten wynosił odpowiednio 18\% i 16\% (Inchley i in. 2016).

Wraz z obniżaniem się wieku inicjacji seksualnej nie następuje jednak obniżenie wieku, w którym dzieci otrzymują rzetelną, dostosowaną do potrzeb i sytuacji, adekwatną i popartą argumentami naukowymi wiedzę z zakresu ludzkiej seksualności. Niezmiennie od lat trwa w kraju dyskusja nad tym, czy edukacja seksualna jest potrzebna, czy może prowadzi jedynie do seksualizacji dzieci (cokolwiek miałoby to oznaczać) i rozbudzenia ich popędów. Warto zaznaczyć, że faktycznie idea edukowania o sferze cielesnej człowieka jest skorelowana z historycznym wyodrębnianiem się okresu zwanego adolescencją, który rozgraniczył fazy dzieciństwa i młodości w życiu człowieka i był początkowo wiązany głównie z pojawieniem się potrzeb seksualnych (Walęcka-Matyja 2009; Bühler 1999). Obecnie jednak podkreśla się, że seksualność to nie tylko sfera relacji z innymi osobami, ale także element indywidualnego rozwoju, który aby przebiegał w sposób prawidłowy, potrzebuje właściwych wzorców. Zgodnie z zaleceniami WHO (WHO 2010) te wzorce powinny być prezentowane już na etapie przedszkolnym, co służyć ma zabezpieczeniu interesów jednostki, przeciwdziałaniu krzywdzeniu dzieci, a także, na późniejszym etapie, zwiększeniu świadomości osób młodych w zakresie ryzyka i konsekwencji rozpoczynania współżycia. Co istotne, międzynarodowe wytyczne (UNESCO 2009) wskazują również na fakt, iż seksualność człowieka nie jest konstruktem uniwersalnym, a na jej postrzeganie i ochronę wpływ mają takie czynniki, jak kultura danego państwa, tradycja czy zwyczaje (Weeks 1986; Seidman 2012). Takie rozumienie seksualności oznacza, że każde społeczeństwo może odmiennie ją definiować i z niej korzystać, wprowadzając swoiste normy i zwyczaje. 
W Polsce obowiązek prowadzenia zajęć z edukacji seksualnej wynika z ustawy o planowaniu rodziny, ochronie płodu ludzkiego i warunkach dopuszczalności przerywania ciąży (Dz.U. z 1993 r., Nr 17, poz. 78), natomiast granice tego obowiązku uszczegóławiają dwa rozporządzenia Ministra Edukacji (Dz.U. z 2012 r., poz. 977; Dz.U. z 2014 r., poz. 395). Wpisany w podstawę programową przedmiot „Wychowanie do życia w rodzinie” funkcjonuje jako częściowo fakultatywny od V klasy podstawowej, czyli pierwszą styczność z tą tematyką mają dzieci w wieku 12-13 lat. Badania dotyczące treści przekazywanych na tych zajęciach wskazują, że jest to niestety często wiedza nieadekwatna, nienaukowa i oparta na głęboko zakorzenionej tradycji patriarchatu i uprzedmiotowienia kobiet, mierząc ich wartość przez pryzmat macierzyństwa i małżeństwa (Abramowicz 2011; PONTON 2009, 2014, 2016). Nie powinno więc dziwić, że badania Ewy Włodarczyk (2008) dotyczące postaw młodzieży wobec macierzyństwa i jego kulturowej kreacji pokazały, iż seksualność kobiet jest silnie skorelowana z potrzebą posiadania dziecka, co potwierdza tylko oddziaływanie czynników kulturowych.

Jednym z przykładów szkolnych oddziaływań jest promowanie przedmałżeńskiej abstynencji seksualnej jako odpowiedzi na swobodę seksualną ukazywaną w mediach czy w Internecie (Węglarczyk 2009; Øistein, Endsjø 2011), zamiast wprowadzania realnych programów uświadamiających w zakresie istniejących zagrożeń i uczących asertywności, poszanowania granic i ochrony własnej prywatności niezależnie od stanu cywilnego jednostki. Trudno więc się dziwić, że młodzi ludzie znajdujący się w okresie intensywnego rozwoju fizycznego, zauważający swoją seksualność, poszukują wiedzy w innych źródłach, najchętniej w mediach i Internecie, które to środki przekazu bardzo często prezentują nieprawidłowy, wypaczony obraz ludzkiej cielesności (Dines 2012). Skutkować to może wczesną inicjacją seksualną, a w konsekwencji również niekiedy przedwczesnym rodzicielstwem. Warto zaznaczyć jedynie na marginesie, że zarówno edukacja domowa (PONTON 2011), jak i edukacja oferowana przez specjalistów z zakresu ochrony zdrowia, (Dz.U. z 2017 r., poz. 1318) nie są w Polsce szeroko dostępne.

Przykład Francji daje nam możliwość wskazania jeszcze jednego związku między ciążami nastolatek a prowadzoną polityką dotyczącą ochrony zdrowia oraz praw reprodukcyjnych i seksualnych. Jak wskazują bowiem badania, Francja jest krajem, w którym odsetek ciąż nastolatek jest jednym z najniższych, przy najwyższym odsetku stosowania przez kobiety antykoncepcji hormonalnej (Kempińska 2017). W Polsce natomiast dostęp ten jest bardzo ograniczony zarówno przepisami prawa, praktyką ich stosowania, jak również cenami produktów. Może to w sposób znaczący wpływać na liczbę nastoletnich matek.

Należy jednak podkreślić, że na zjawisko ciąż nastolatek wpływ ma wiele różnych czynników i trudno wskazać jedną bezpośrednią przyczynę, która decyduje o zwiększeniu lub zmniejszeniu ich liczby w kraju. W Polsce bowiem liczba nastoletnich ciąż systematycznie się zmniejsza mimo braku realnego dostępu do edukacji seksualnej czy antykoncepcji. Przyczyną tego stanu rzeczy nie jest jednak prawdo- 
podobnie większa samoświadomość nastolatek, ale przykładowo niż demograficzny czy zwiększająca się dostępność aborcji farmakologicznej.

W literaturze przedmiotu, bazując na prowadzonych badaniach w grupach kobiet, które jako nastolatki urodziły dzieci, wskazuje się czynniki, które zwiększają prawdopodobieństwo przedwczesnego macierzyństwa. Należą do nich przede wszystkim: niski status społeczno-ekonomiczny, niskie poczucie własnej wartości, niski poziom kompetencji społecznych, niski poziom edukacji seksualnej w domu i szkole, problemy szkolne, dorastanie w monoparentalnej rodzinie i konflikty bądź doświadczanie przemocy w domu (np. Skowrońska-Pućka 2016; Więcławska 2005; Skowrońska-Zbierzchowska 2010). Dodatkowo, co szczególnie istotne w kontekście młodych matek, pozostających pod opieką instytucjonalną, istnieją wyraźne różnice między dziewczętami, które miały szanse na wychowywanie swoich dzieci w rodzinie biologicznej lub prawnej a dziewczętami, które nie posiadając tego wsparcia, trafiły przykładowo do Domów Samotnej Matki (Więcławska 2005). Różnice dotyczą kompetencji poznawczych, emocjonalnych, ewaluatywnych, a także w zakresie poczucia sensu życia. Niestety, matki pozbawione wsparcia osób najbliższych w każdym z tych obszarów posiadają znaczące deficyty, które utrudniają im prawidłowe spełnianie swojej roli. Takie wyniki powinny nam uświadomić, że system opieki instytucjonalnej nie jest optymalnym miejscem, do którego powinny trafiać młode matki.

\section{Prawny wymiar wczesnego macierzyństwa}

Każde dziecko w Polsce, zgodnie z obowiązującymi przepisami prawa, powinno być objęte szczególną ochroną. Wynika ona zarówno z regulacji międzynarodowych, takich jak Konwencja o Prawach Dziecka (Dz.U. z 1991 r., Nr 120, poz. 526), jak i krajowych. W artykule 72 Konstytucji (Dz.U. z 1997 r., Nr 78, poz. 483) zagwarantowana jest ochrona praw dziecka, w artykule 70 natomiast wpisany został obowiązek nauki do 18. roku życia, a artykuł 68 przyznaje każdemu prawo do ochrony zdrowia. Z perspektywy młodych matek istotna jest również specjalna ochrona i opieka macierzyństwa zawarta w artykule 18, gwarancja ochrony życia prywatnego i rodzinnego, a także uwzględniania dobra rodziny w prowadzonej polityce społecznej i gospodarczej - odpowiednio w artykule 47 i 71 . Powyższe przepisy powinny zostać uszczegółowione w konkretnych aktach prawnych, przykładowo w kodeksie cywilnym, rodzinnym i opiekuńczym, w ustawach z zakresu praw pacjenta czy pomocy społecznej, ale także w regulacjach karnych. Ustawodawca powinien również uwzględnić specyficzną sytuację młodych kobiet rodzących dzieci i zagwarantować, że zarówno ich dobro, jak i dobro ich dzieci zostanie objęte ochroną. Niestety nie zawsze tak się dzieje.

Ustawodawca, realizując przewidzianą w Konstytucji ochronę zdrowia, wprowadził zakaz kontaktów seksualnych z dzieckiem poniżej 15. roku życia zapisany 
w kodeksie karnym w artykule 200 (Dz.U. z 2018 r., poz. 1600). Wskazuje się, że indywidualnym przedmiotem ochrony tego przepisu jest prawidłowy rozwój psychiczny i fizyczny małoletniego (Rodzynkiewicz 1999), ale także swoboda decyzji związanych z życiem płciowym (Warylewski 2010) czy również ochrona przed społecznymi konsekwencjami związanymi z przedwczesnym macierzyństwem lub ojcostwem (Bielski 2008). Ustawodawca uznał, że dziecko niemające ukończonych 15 lat nie może świadomie udzielić zgody na kontakt o charakterze seksualnym, nawet jeśli partnerem byłaby osoba w podobnym wieku. Jednocześnie jednak stwierdza, że osiągnięcie 15 lat jest wystarczające, aby uznać, że dziecko ma wiedzę i odpowiednie rozeznanie, które ochroni je przed negatywnymi konsekwencjami relacji seksualnych. Dodatkowo partnerem takiego dziecka może wtedy być osoba w dowolnym wieku, również znacznie od niej starsza. Biorąc pod uwagę poziom edukacji seksualnej w Polsce, można jednak mieć pewne wątpliwości, czy dzieci właściwą wiedzę posiadają. Podczas dyskusji na temat zmian w kodeksie karnym wprowadzanych w pośpiechu w maju 2019 r. ustawodawca chyba nawet zauważył ten problem. Jedynym zaproponowanym rozwiązaniem było jednak podwyższenie wieku zgody z 15 do 16 lat.

Konsekwencją tej zmiany byłoby przede wszystkim zwiększenie statystyk w zakresie karania (w 2018 r. 198 dziewcząt w wieku 15 lat i mniej urodziło dzieci; 16-latek było już 542 (GUS 2018), a przecież nie każdy kontakt seksualny kończy się ciążą), z dużym prawdopodobieństwem nie zmniejszając liczby nastolatków wchodzących w relacje seksualne. Szczególnie, że ich świadomość w zakresie wieku zgody i konsekwencji prawnych wprowadzenia takiego przepisu w kodeksie karnym jest zazwyczaj niewielka.

Wynika to również ze wspomnianych wcześniej ograniczeń w zakresie dostępu do poradnictwa specjalistycznego, czyli usług medycznych. Ustawa o prawach pacjenta i Rzeczniku Praw Pacjenta stanowi, że osoby do 16. roku życia nie muszą otrzymywać pełnej informacji na temat swojego stanu zdrowia, a dodatkowo do 18. roku życia przy korzystaniu ze świadczeń medycznych wymagana jest obecność opiekuna prawnego bądź faktycznego osoby małoletniej. W znacznym stopniu ogranicza to dostęp chociażby do opieki ginekologicznej, która mogłaby uchronić dziewczęta przed ryzykiem zajścia w ciążę. Szczególnie jeśli rodzic bądź opiekun nie ma świadomości, że jego dziecko rozpoczęło już współżycie płciowe.

Konsekwencją polityki państwa, która ogranicza dostęp do wiedzy i usług specjalistycznych, mogą być niestety ciąże małoletnich. Próbując nieco „naprawić system”, ustawodawca wprowadza przepisy dotyczące kontynuowania nauki przez młode matki, ułatwiając im dzielenie czasu pomiędzy obowiązki szkolne a domowe. Są one zawarte w ustawie o planowaniu rodziny, ochronie płodu ludzkiego i warunkach dopuszczalności przerywania ciąży, jednak są na tyle ogólne, że każda placówka oświatowa zobowiązana do ułatwienia takim dziewczętom zaliczenia przedmiotów i egzaminów, a także udzielenia urlopów w nauce, musi samodzielnie wypracowywać konkretne rozwiązania (Bunio-Mroczek, Warzywoda-Kruszyńska 
2010). Niestety, w praktyce może okazać się, że młode matki skończą swoją edukację w wieku 18 lat, gdyż próby łączenia opieki nad dzieckiem z nauką są niezwykle trudne, wymagające dużego poświęcenia, jak również i nakładów finansowych. Niski poziom wykształcenia jest cechą charakterystyczną grupy dziewcząt wcześnie zachodzących w ciążę i nieotrzymujących wsparcia od najbliższej rodziny (Skowrońska-Zbierzchowska 2010).

Dodatkowym problemem jest kwestia władzy rodzicielskiej, która co do zasady może przysługiwać tylko osobom posiadającym pełną zdolność do czynności prawnych, czyli pełnoletnim. W sposób znaczący ogranicza to prawa małoletnich, które chciałyby nie tylko opiekować się swoimi dziećmi, ale także wykonywać wobec nich wszelkie uprawnienia związane $\mathrm{z}$ rodzicielstwem. Ustawodawca częściowo rozwiązał ten problem, dając możliwość kobietom, które ukończyły 16. rok życia, na złożenie wniosku do sądu opiekuńczego o wydanie zgody na wcześniejsze zawarcie małżeństwa (Dz.U. z 2017 r., poz. 682, art. 10). W konsekwencji zawarcia małżeństwa zdobywają one pełną zdolność do czynności prawnych i mogą uzyskać również władzę rodzicielską nad swoimi dziećmi. Z badań Urszuli Kempińskiej $(2005,2012)$ wynika, że z biegiem lat coraz mniej osób decyduje się na takie rozwiązanie. Najnowsze opracowanie badaczki (2017) zawiera dane z roku 2003 i 2014, które wyraźnie wskazują na to, że liczba wcześniej zawieranych małżeństw spada, z 829 w roku 2003, do jedynie 194 w 2014. Oznacza to, że powoli małżeństwo traci walor gwarancji prawidłowego rodzicielstwa, a ciężarne dziewczęta nie odczuwają już presji wychodzenia za mąż. Może to oznaczać, że potrzebne są nowe rozwiązania, bardziej adekwatne do społecznej rzeczywistości, w jakiej żyjemy. Jednym z tych rozwiązań mogłoby być umożliwienie małoletnim kobietom wystąpienia $\mathrm{z}$ wnioskiem do sądu opiekuńczego o rozważenie kwestii przyznania im pełnej zdolności do czynności prawych z chwilą urodzenia dziecka, co skutkowałoby możliwością sprawowania pełnej opieki nad dzieckiem.

Władza rodzicielska jest bowiem niezwykle istotna. Zgodnie z kodeksem rodzinnym i opiekuńczym pozwala nie tylko na sprawowanie bieżącej opieki nad dzieckiem, ale także na podejmowanie decyzji w jego ważnych sprawach, reprezentowanie go przed różnymi instytucjami czy też otrzymywanie pomocy ze strony państwa na jego utrzymanie i rozwój. Jeśli matka dziecka jest małoletnia, należy przed sądem wyznaczyć opiekuna prawnego, który będzie reprezentował jego interesy. Nawet bowiem gdy ojciec jest pełnoletni, prawo wymaga sądowego potwierdzenia jego ojcostwa, a tutaj potrzebna jest zgoda opiekuna prawnego dziecka, którym może być tylko osoba posiadająca pełną zdolność do czynności prawnych. Oznacza to więc, że w przeciwieństwie do urodzenia dziecka w związku małżeńskim, który gwarantuje domniemanie ojcostwa, w przypadku urodzeń pozamałżeńskich procedury są bardziej sformalizowane i mogą wymagać ingerencji sądu.

W przypadku rodzicielstwa osób bardzo młodych pojawia się jeszcze jeden problem. Okazuje się bowiem, że związki młodych rodziców są nietrwałe, dziecko 
najczęściej pozostaje pod opieką matki, a ojciec niestety istnieje w jego życiu tylko na papierze. Nie oznacza to jednak, że traci on automatycznie władzę rodzicielską. Nadal jest uprawniony do sprawowania opieki nad dzieckiem, a także jest współodpowiedzialny za podejmowanie ważnych decyzji w jego życiu. Jego nieobecność może powodować trudności w tak prowizorycznych aspektach życia, jak zapisanie dziecka do żłobka czy przedszkola. Aby tę władzę ograniczyć lub ojca jej pozbawić, trzeba wykazać przed sądem, że istnieją ku temu ważne przesłanki. Proces nie jest szybki, a decyzja nigdy nie jest pewna. Dziewczęta, które zdają sobie sprawę z tych trudności, mogą nie uwzględniać ojca w oficjalnych dokumentach, co pozwoli im w przyszłości sprawować władzę rodzicielską niepodzielnie.

Takie rozwiązanie eliminuje jeszcze jeden kłopot. Obecnie państwo gwarantuje wypłaty świadczeń na dzieci w postaci wielu różnych zasiłków. W przypadku niektórych niezbędne jest wykazanie, że ojciec dziecka partycypuje (bądź nie) w kosztach utrzymania dziecka, co w praktyce oznacza obowiązek złożenia pozwu o alimenty. Należy podkreślić, że w przypadku tej grupy są to bardzo często działania pozorne. Matka lub opiekun prawny dziecka pozywa ojca o alimenty, sąd wydaje postanowienie o zabezpieczeniu interesów dziecka w postaci konkretnej kwoty i zobowiązuje ojca do jej przekazywania raz w miesiącu, i na podstawie tych działań zobowiązane urzędy mogą wypłacać dodatkowe świadczenia pieniężne. Pozorność tych działań polega na tym, że ojciec prawdopodobnie nie będzie tych alimentów płacił, sprawa trafi do komornika, a zadłużenie będzie systematycznie rosło. Na podstawie bezskutecznej egzekucji można oczywiście wnioskować o wypłaty z funduszu alimentacyjnego, co częściowo może zabezpieczyć egzystencję dziecka, jednak należy również wskazać, że generuje to ogromne koszty społeczne. Od unikania legalnego zatrudnienia przez ojca w przyszłości, które pozwoliłoby komornikowi ściągać z niego alimenty, do postępowań karnych za przestępstwo niealimentacji.

Problemów pojawiających się w przypadku przedwczesnego rodzicielstwa nie da się niestety rozwiązać jedynie przepisami prawa. Nawet jeśli wprowadzi się rozwiązania zwiększające gwarancje ochrony praw dziecka, w przypadku młodych rodziców pojawia się wiele dodatkowych dylematów, których rozwiązanie zależy od różnych czynników, również pozaprawnych. Budowanie odpowiedzialności za zdrowie, życie i egzystencję dziecka staje się kluczowym elementem pracy z przyszłymi rodzicami. Posiadanie wsparcia ze strony rodziny i osób najbliższych, czerpanie dobrych wzorców z najbliższego otoczenia i budowanie poczucia współodpowiedzialności daje szanse na to, aby nawet w przypadku wczesnego macierzyństwa czy rodzicielstwa nie zostały naruszone prawa dziecka - zarówno tego nowo narodzonego, jak i jego małoletnich rodziców. Sytuacja bardzo się komplikuje, gdy rodzina jest dysfunkcyjna, a nastoletnia matka umieszczona jest w placówce sprawującej nad nią opiekę instytucjonalną. 


\section{Wczesne macierzyństwo w systemie opieki instytucjonalnej - studium przypadków}

Każdego roku zdarzają się przypadki nieletnich rodzących dzieci. Są to osoby, które ze względu na demoralizację bądź czyny karalne, których się dopuściły, umieszczane są w placówkach wychowawczych i resocjalizacyjnych, czyli przykładowo w młodzieżowych ośrodkach wychowawczych lub zakładach poprawczych. Dodatkowo, należy zaznaczyć, że również w placówkach wychowawczych, takich jak domy dziecka czy rodziny zastępcze, mogą zdarzać się podobne sytuacje. Jest to więc całkiem liczna grupa dziewcząt, które pozbawione rodzinnego wsparcia muszą odnaleźć się w trudnej rzeczywistości bycia matką.

W literaturze podkreśla się, że wczesne macierzyństwo jest „zdarzeniem krytycznym niepunktualnym" (Skowrońska-Pućka 2016: 11). Występuje ono bowiem zbyt wcześnie z punktu widzenia rozwoju człowieka, a także może prowadzić do jego zaburzenia (Brzezińska 2000, 2003). Istotne są również wyniki badań nad grupami dziewcząt przebywających w placówkach opiekuńczo-wychowawczych wskazujące na fakt, iż ich umieszczenie w opiece instytucjonalnej było zazwyczaj rezultatem długotrwałej i pogłębiającej się niewydolności rodzin pochodzenia, który miał istotny wpływ na wiele sfer ich codziennego funkcjonowania (Skowrońska-Pućka 2016). To przejmowanie niewłaściwych wzorców z domu rodzinnego miało również wpływ na późniejsze funkcjonowanie dziewcząt, a także na podejmowanie ryzykownych zachowań seksualnych, których konsekwencją mogły być ciąże.

Przez lata problem dziewcząt przebywających w placówkach i rodzących dzieci był właściwie niezauważany przez system. Do tego stopnia, że powszechną praktyką było odbieranie im dzieci zaraz po urodzeniu na mocy decyzji sądu, który może również bez zgody małoletniej matki, działając rzekomo w interesie nowo narodzonego dziecka doprowadzić do ich rozdzielenia. Mogło to wynikać z przekonania, że dziewczęta, które wychowywały się w niesprzyjających warunkach, nie posiadały odpowiedniego wsparcia od rodziny, nie będą po prostu dobrymi matkami. Fundacja po DRUGIE, która od 8 lat zajmuje się wspieraniem młodych osób w kryzysie, zauważyła ten problem i rozpoczęła długotrwałą walkę o jego rozwiązanie (Sikora 2013). Jednocześnie jednak, oprócz działań dotyczących wprowadzenia faktycznych zmian w prawie, w swojej codziennej pracy wspiera młode matki w zakresie uzyskiwania opieki nad dziećmi i regulowania ich sytuacji osobistej. Od początku istnienia zgłosiło się do niej kilkadziesiąt nastolatek z różnych placówek i instytucji. Na podstawie tych doświadczeń, a także konkretnych historii (Szczepanik, Sikora 2014) można wskazać obszary, które wymagają szczególnej uwagi.

Podstawowym problemem jest niestety nie tylko brak wsparcia ze strony najbliższych, a w związku z tym niekiedy faktyczna nieumiejętność poradzenia sobie z sytuacją kryzysową, jaką jest urodzenie dziecka, ale właśnie powszechne przeświadczenie wspomniane wcześniej, że takie dziewczyny nigdy nie będą „dobrymi 
matkami”. Ciągle zdarzają się przypadki, gdy decyzja o odebraniu dziecka zostaje podjęta jeszcze w szpitalu, chwilę po porodzie. Dziewczęta są namawiane przez swoich opiekunów do dobrowolnego oddania dziecka do adopcji lub straszone tym, że i tak nie będą mogły sprawować nad nim bezpośredniej pieczy, bo prawo lub regulamin placówki tego nie przewiduje. Faktycznie, do tej pory nie ma przepisów umożliwiających stały pobyt matek z dziećmi w zakładach poprawczych, ale takie sytuacje dotyczą również młodzieżowych ośrodków wychowawczych czy nawet domów dziecka. Trafiały do Fundacji dziewczęta, które były rozdzielane z dziećmi, ponieważ przez 9 miesięcy ciąży nikt nie zadbał o miejsce w młodzieżowym ośrodku wychowawczym przygotowanym do sprawowania opieki nad matką i dzieckiem, lub takie z domów dziecka, gdzie regulamin zabraniał przyjmowania dzieci poniżej 10. roku życia.

Zdarzają się też przypadki, kiedy młode matki są zwalniane do rodzinnych domów, aby móc opiekować się swoim dzieckiem, mimo że warunki tam panujące nie stanowią żadnych gwarancji prawidłowej opieki, zarówno nad dziewczyną, jak i jej potomstwem. Pod opieką Fundacji była również osiemnastolatka z umiarkowaną niepełnosprawnością intelektualną, która urodziła już trójkę dzieci, z których tylko jedno było jej czasowo powierzone pod opiekę. Dziewczyna była umieszczana w różnych placówkach, również w domu pomocy społecznej, a ostatecznie trafiła do schroniska dla bezdomnych. Tam zaszła w kolejną ciążę, a system po raz kolejny dziecko jej odebrał. Nikt jednak nie zastanowił się nad skutkami psychologicznymi, ale także fizycznymi donoszenia 4 ciąż w tak młodym wieku i czy może nie należałoby wdrożyć środków mogących uregulować lub czasowo ograniczyć jej płodność, chociażby poprzez założenie wkładki domacicznej, który to zabieg jest refundowany przez NFZ. Wpływ na te niekiedy dramatyczne sytuacje ma na pewno również upolitycznienie macierzyństwa (Hryciuk, Korolczuk 2015), w wyniku którego szczególną ochroną obejmuje się płód, podczas gdy los matki i nowo narodzonego dziecka nie jest już dla wielu tak istotny.

Charakterystyczne jest to, że problem rozdzielania matek z dziećmi poprzez umieszczanie tych pierwszych w instytucjach zamkniętych został zauważony już bardzo dawno temu. W latach siedemdziesiątych XX w. zrodziła się idea resocjalizacji przez miłość, na fali której utworzone zostały domy matki i dziecka przy zakładach karnych dla kobiet (Matysiak-Błaszczyk 2016). Łącznie w Zakładzie Karnym w Krzywańcu i Grudziądzu jest około 60 miejsc dla kobiet z dziećmi, które mogą sprawować nad nimi opiekę aż do ukończenia 3. roku życia (a czasem dłużej). Liczba 60 znajduje się również w raporcie Fundacji po DRUGIE dotyczącym dziewcząt przebywających w placówkach resocjalizacyjnych, czyli zakładach poprawczych, i zachodzących w ciąże (Sikora 2013: 3). One jednak nie mają możliwości opieki nad dziećmi podczas pobytu w zakładzie poprawczym - albo więc są od dzieci oddzielane, albo zwalniane z zakładów, niekiedy nawet mimo świadomości kadry, że proces resocjalizacji czy też pozytywnej readaptacji mógł nie zostać ukończony (Szczepanik 2013). 
Można odnieść wrażenie, że w przypadku młodych matek z placówek opiekuńczo-wychowawczych lub resocjalizacyjnych system z góry zakłada niepowodzenie macierzyńskie, projektując schematy, które dziewczęta wyniosły z własnych, dysfunkcyjnych domów rodzinnych na ich przyszłe rodziny. $W$ efekcie nie daje im się szansy na sprawdzenie własnych możliwości, a także często odmawia im się wsparcia $\mathrm{w}$ procesie stawania się matką. Jak wynika jednak $\mathrm{z}$ analiz wielu indywidualnych przypadków dziewcząt, które trafiły pod opiekę Fundacji po DRUGIE, ich silna, niespełniona potrzeba miłości, potrzeba bycia kochanym, stanowić może dobry i solidny fundament, na którym można osadzić podwaliny dobrego, spełnionego, a także szczęśliwego macierzyństwa. Nie odbędzie się to jednak bez właściwego, szeroko zakrojonego wsparcia, uwzględniającego nie tylko przykładowo kwestie mieszkaniowe czy finansowe, ale przede wszystkim potrzeby emocjonalne i psychologiczne, a także naukę kompetencji rodzicielskich i zaprojektowanie nowych wzorów zachowań. Takich, które pozwolą przerwać schemat powtarzania niewłaściwych wzorców wyniesionych przez nie z domu pochodzenia. Często brakuje zrozumienia i chęci, aby takiej pomocy udzielić.

Ciekawym przykładem zmian, które miały zwiększyć ochronę praw dziecka, jest wprowadzenie do kodeksu karnego art. 240 penalizującego niezgłoszenie do organów ścigania niektórych przestępstw, w tym przestępstwa kontaktów seksualnych z dzieckiem poniżej 15. roku życia. Obowiązek ten objął też kadrę placówek, gdzie przebywają małoletnie dziewczęta, które zaszły w ciążę przed 15. rokiem życia. W sposób oczywisty karalność takich przypadków wpływa na sytuację osobistą przyszłej matki. W roku 2018 w Schronisku dla Nieletnich i Zakładzie Poprawczym w Warszawie-Falenicy był jeden taki przypadek. Dziewczyna w wieku 15 lat i w 5 miesiącu ciąży trafiła do nich z Domu Dziecka. Jej partner miał wtedy 19 lat. Dziewczyna bardzo chciała, aby dziecko nosiło nazwisko ojca, ponieważ jej rodzina nigdy nie okazała jej wsparcia, on chciał wspierać ją w rodzicielstwie i łożyć na utrzymanie dziecka. Niestety, wszczęcie postępowania karnego pokrzyżowało te plany. Chłopak przestał się z nią kontaktować, Zakład Poprawczy musiał w trybie pilnym zorganizować jej przeniesienie do innej placówki, w której mogłaby sprawować bieżącą pieczę nad swoim dzieckiem, ona musiała pogodzić się z faktem, że wizja szczęśliwej, pełnej rodziny nie miała żadnych szans na ziszczenie się. Ten przypadek pokazuje jednak dwie istotne kwestie. Pierwsza dotyczy syste$\mathrm{mu}$ instytucjonalnej opieki nad dziećmi i poszanowania ich praw. Kierowanie dziewczynki w ciąży do placówki, w której nie może przebywać ze swoim dzieckiem jest $\mathrm{w}$ pewnym sensie $\mathrm{z}$ góry podjętą decyzją o rozdzieleniu matki i dziecka. Z drugiej strony należy zastanowić się, czemu ma służyć taki bezwzględny zakaz kontaktów seksualnych $\mathrm{z}$ małoletnimi poniżej 15. roku życia, w szczególności wtedy, gdy na kary pozbawienia wolności skazujemy osoby będące $\mathrm{w}$ bardzo zbliżonym wieku. W wielu krajach europejskich i na świecie wprowadza się przepisy dekryminalizujące rówieśnicze kontakty seksualne, zakładając, że istnieją inne, poza prawno-karne mechanizmy regulacji zachowań seksualnych młodzieży. 
W Polsce jednakże dąży się do zwiększenia punitywności, zaostrzenia kar i poszerzenia zakresu kryminalizowanych zachowań, bez nawet prób uwzględniania społecznej perspektywy pewnych zjawisk. Wydaje się, że w okresie długofalowym taka polityka nie przyniesie pozytywnych rezultatów.

Zdarzają się oczywiście również przypadki, w których odebranie młodej matce dziecka jest w pełni uzasadnione i w interesie obu stron. Nie oznacza to jednak, że dziewczyna jest „złą matką”, a jedynie, że w danym momencie swojego życia nie udźwignęła ciężaru macierzyństwa i nie była w stanie w pełni poświęcić się dziecku. Czasem po prostu potrzebowała czasu, aby sama dorosnąć i przejąć odpowiedzialność za swoje życie, a proces ten wymagał pracy, determinacji i konsekwencji. W takich przypadkach Fundacja po DRUGIE wspiera nastoletnie matki w procesie rezygnacji z władzy rodzicielskiej i oddania dziecka do adopcji, licząc, że decyzja o daniu mu szansy na prawdziwy dom, a nie „placówkową” rzeczywistość będzie najkorzystniejsza dla obu stron. Dziewczęta, wiedząc z autopsji, jak wygląda życie w systemie opieki instytucjonalnej, kierując się nieukrywaną miłością do dziecka, potrafią z niego zrezygnować, aby dać mu lepszą przyszłość. Po kilku latach jako dorosłe kobiety podejmują świadomą decyzję o macierzyństwie i potrafią się w nim odnaleźć, tworząc szczęśliwe rodziny. Okazuje się, że to, co jest im potrzebne, to indywidualnie sprofilowane wsparcie, brak potępienia dla podejmowanych decyzji i wiara, że będą w stanie stworzyć dla swoich dzieci taki dom, jakiego zawsze im brakowało.

\section{Zamiast podsumowania: dobro dziecka czy... dobro dziecka?}

Truizmem jest twierdzenie, że rodzina to „podstawowa komórka, w której dzieci i młodzież zdobywają podstawowe pojęcia o życiu społecznym, w której kształtują się podstawy osobowości, przekonań, postaw, światopoglądu oraz pojęć etyczno-moralnych" (Jordan 2008: 154). Powinno być to miejsce bezpieczne, przyjazne i uważne na potrzeby dzieci, miejsce, w którym jednostki nabywają podstawowe kompetencje społeczne, uczą się, jak prawidłowo spełniać swoje role w społeczeństwie i tego, jak w przyszłości będą wyglądały ich relacje z innymi. Brak rodziny (bądź przebywanie w rodzinie dysfunkcyjnej) powinien skutkować natychmiastową reakcją państwa, którego obowiązkiem jest zagwarantować dziecku bezpieczne miejsce dla prawidłowego rozwoju. Tworzenie i funkcjonowanie instytucji zobowiązanych do opieki i wychowania powinno opierać się na założeniu wspierania i budowania więzi podobnych do relacji występujących $\mathrm{w}$ rodzinie. $\mathrm{W}$ takim środowisku dostrzega się problemy i dąży do ich rozwiązania, biorąc pod uwagę dobro każdej ze stron. Mimo przyjęcia prawnych gwarancji poszanowania praw dziecka, jako praw przysługujących również małoletnim matkom, w praktyce zauważyć można, że dziewczęta przebywające poza rodziną pochodzenia rzadziej otrzymują wymagane wsparcie, a ich prawa niejednokrotnie są naruszane. Warto podkreślić, 
że odbierając im dzieci, bazując na przekonaniu, że będą powielały schematy wyniesione z domu, w pewnym sensie obnaża się również nieudolność systemu opieki instytucjonalnej, który nie jest w stanie przekazać im tych wzorców i wartości, które są w społeczeństwie uznawane za prawidłowe.

Przedwczesne macierzyństwo jest zawsze zdarzeniem kryzysowym wymagającym podjęcia dodatkowych, adekwatnych do indywidualnej sytuacji działań, których celem jest zagwarantowanie poszanowania praw dwójki dzieci: matki i jej dziecka (Żelazkowska 2016). Charakterystyczne jest również to, że - jak wynika z badań (tamże) - dotyka ono częściej nastolatek wywodzących się z domów o niskim statusie społeczno-ekonomicznym i takich, w których dzieciom poświęca się mniej uwagi i w mniejszym stopniu zauważane i realizowane są ich indywidualne potrzeby. Co więcej, podkreśla się, że wczesne macierzyństwo zmniejsza szanse kobiet na kontynuację nauki, na rozwój kariery zawodowej, zazwyczaj skorelowane jest z posiadaniem większej liczby dzieci pojawiających się w krótkich odstępach czasu (Skowrońska-Pućka 2016), co w konsekwencji prowadzić może do powielania schematów życia rodzinnego nastolatek. Świadomość takich konsekwencji wczesnych ciąż powinna intensyfikować oddziaływania wychowawcze i socjalizacyjne w systemie opieki instytucjonalnej, którego głównym celem jest przecież nie jedynie zapewnienie czasowej opieki do chwili osiągnięcia przez dziecko pełnoletniości, ale zastąpienie rodziny i przygotowanie młodzieży do odpowiedzialnego, świadomego i pełnowartościowego uczestnictwa w życiu społecznym. Warto więc przyjrzeć się nie tylko prawnym regulacjom małoletniego macierzyństwa, ale sposobom ich wykorzystywania w praktyce. Należy to jednak robić przez pryzmat poszanowania praw dwóch osób - dziecka, którym jest jeszcze małoletnia matka, i dziecka, które ma prawo urodzić się w rodzinie respektującej jego prawa i prawidłowo wypełniającej swoje wobec niego obowiązki.

\section{Bibliografia}

Abramowicz M. (red.) (2011) Wielka (nie)obecna - o edukacji antydyskryminacyjnej $w$ systemie edukacji formalnej $w$ Polsce. Raport z badań, Warszawa, Towarzystwo Edukacji Antydyskrymiacyjnej TEA.

Bielski M. (2008) w: Kodeks karny. Część szczególna, A. Zoll (red.), t. II, Warszawa, Wolters Kluwer Polska Sp. z o.o., s. 647.

Bień A., Iwanowicz-Palus G., Włoszczak-Szubzda A., Witkowska M. (2015) Ciężarne niepełnoletnie - współczesny problem bio-psycho-społeczny, Medycyna Ogólna i Nauki o Zdrowiu, t. 21, nr 2, s. 125-131.

Brzezińska A. (2000) Społeczna psychologia rozwoju, t. 3, Warszawa, Wydawnictwo Scholar. 
Brzezińska A. (2003) Wydarzenia punktualne i niepunktualne w okresie dzieciństwa i dorastania, „Remedium”, nr 12 (130), s. 47-48.

Bühler Ch. (1999) Bieg życia ludzkiego, tłum. E. Cichy, J. Jarosz, Warszawa, Wydawnictwo Naukowe PWN.

Bunio-Mroczek P., Warzywoda-Kruszyńska W. (2010) Wczesne rodzicielstwo jako zagrożenie biedq̨ i wykluczeniem społecznym, Łódź, Wydawnictwo Biblioteka, Instytut Socjologii Uniwersytetu Łódzkiego, Fundacja Instytut Inicjatyw Społecznych, s. 17.

Currie C., Zanotti C., Morgan A., Currie D., de Looze M., Roberts C., Samdal O., Smith O. F. R., Barnekow V. (2012) Social determinants of health and well-being among young people,Health Behaviour w: School-Aged Children (HBSC), Study: International Report From The 2009/2010 Survey, Copenhagen, WHO Regional Office for Europe (http://www.euro.who.int/_data/assets/pdf_file/0003/163857/Social-determinantsof-health-and-well-being-among-young-people.pdf [dostęp: 12.11.2019].

Dines G. (2012) Pornoland. Jak skradziono naszq seksualność, tłum. K. Dajksler, Poznań, Wydawnictwo $\mathrm{W}$ drodze.

Hryciuk R. E., Korolczuk E. (2015) Niebezpieczne zwiqzzi. Macierzyństwo, ojcostwo i polityka, Warszawa, Wydawnictwo Uniwersytetu Warszawskiego.

Imieliński K (1992) Medycyna seksualna. Patologia i profilaktyka, Warszawa, Oficyna Wydawnicza PCK.

Inchley J, Currie D., Young T., Samdal O., Torsheim T., Augustson L., Mathison F., Aleman-Diaz A., Molcho M., Weber M., Barnekow V., (2016) Growing up unequal: gender and socioeconomic differences in young people's health and well-being, Health Behaviour in School-Aged Children (HBSC) Study: International Report From The 2013/2014 Survey, World Health Organization (http://www.euro.who.int/_data/assets/pdf file/0003/303438/HSBC-No.7-Growing-up-unequal-Full-Report.pdf [dostęp: 12.11. 2019].

Izdebski Z. (2010) Ryzykowna dekada - seksualność Polaków w dobie HIV/AIDS, Zielona Góra, Wydawnictwo Uniwersytetu Zielonogórskiego.

Izdebski Z., Seksualność Polaków 2011, Raport z badań zrealizowanych przez TNS OBOP na zlecenie Biura Handlowego Polpharma Sp. z o.o. Materiały z konferencji 23.11.2011 (https://docplayer.pl/9773600-Seks-polakow-w-internecie-raportpolpharmy-2010-prof-dr-hab-zbigniew-izdebski.html [dostęp: 18.10.2019].

Izdebski Z., Niemiec T., Wąż K. (2011) (Zbyt)młodzi rodzice, Warszawa, Wydawnictwo Trio.

Jordan M. (2004) Środowisko rodzinne młodzieży o zaburzonej socjalizacji w: Studia i rozprawy z pedagogiki resocjalizacyjnej, Z. Jasiński, I. Mudrecka (red.), Opole, Wydawnictwo Uniwersytetu Opolskiego, s. 145-186. 
Kempińska U. (2005) Małżeństwa młodocianych. Przyczyny i konsekwencje, Włocławek, Wydawnictwo Wyższa Szkoła Humanistyczno-Ekonomiczna we Włocławku.

Kempińska U. (2012), Małżeństwa młodocianych. Ciq̨ża, ślub i co dalej...?, Toruń, Wydawnictwo Edukacyjne AKAPIT.

Kempińska U. (2017) Nieletnie macierzyństwo - problem ogólnoświatowy, Poznań, Instytut Naukowo-Wydawniczy MAIUSCULA sp. z o.o.

Matysiak-Błaszczyk A. (2016) Więzienne macierzyństwo. Studium socjopedagogiczne, Poznań, Wydawnictwo Naukowe UAM.

Mikołajczyk-Lerman G. (2007) Małoletnie rodzicielstwo jako problem psychospołeczny, Polityka Społeczna (8), IPiSS, s. 54-59.

Napieralska E. (2010) Antykoncepcja wśród nastoletnich dziewczq̨t, „Nowiny Lekarskie", nr 1, s. 18-21.

Obuchowska I., Jaczewski A. (2002) Rozwój erotyczny, Warszawa, WSiP.

Øistein Endsjø D. (2011) Seks a religia. Od balu dziewic po święty seks homoseksualny, Warszawa, Czarna Owca.

Rodzynkiewicz M. (1999) w: Kodeks karny. Cześć szczególna. Komentarz do art. 117277 kk., A. Zoll (red.), Kraków, Zakamycze, s. 553.

Seidman S. (2012) Społeczne tworzenie seksualności, tłum. P. Tomanek, Warszawa, Wydawnictwo Naukowe PWN.

Sikora A. (red.) (2013) Sytuacja prawna, społeczna i wychowawcza nieletnich ciężarnych i nieletnich matek przebywających $w$ placówkach resocjalizacyjnych, Raport z realizacji projektu „Chcę być z Tobą MAMO!, Warszawa, Fundacja po DRUGIE.

Skowrońska-Pućka A. (2016) (Przed)wczesne macierzyństwo - perspektywa biograficzna. Diagnoza, pomoc i wsparcie, Poznań, Wydawnictwo Naukowe UAM.

Skowrońska-Zbierzchowska A. (2010) Doświadczenia małoletnich rodziców. Aspekty socjopedagogiczne, Gdańsk, Wydawnictwo Uniwersytetu Gdańskiego.

Szczepanik R. (2013), Miejsce placówki resocjalizacyjnej w systemie wsparcia społecznego nieletnich ciężarnych i matek. Perspektywa wychowawców w: Rozwój i jego wspieranie $w$ perspektywie rehabilitacji i resocjalizacji, D. Müller, A. Sobczak (red.), Łódź, Wydawnictwo Uniwersytetu Łódzkiego, s. 183-201.

Szczepanik R., Sikora A. (2014), Przedwczesne macierzyństwo w biografiach wychowanek placówek resocjalizacyjnych w: Środowiskowy wymiar niedostosowania. Teoriebadania-praktyka, K. Sawicki, K. Konaszewski (red.), Agencja Wydawnicza Ekopress, Białystok, s. 78-89. 
Szukalski P. (2010) Nastoletnie macierzyństwo w Polsce - ujęcie regionalne, „Praca Socjalna", numer specjalny, s. 135-157.

Walęcka-Matyja K. (2009) Struktura rodziny a zróżnicowanie zachowań społecznych i osobowości młodzieży, Łódź, Wydawnictwo Uniwersytetu Łódzkiego.

Warylewski J. (2010) w: Kodeks karny, część szczególna, A. Wąsek, R. Zawłocki (red.), t. I, Duże Komentarze Becka, Wydawnictwo C.H. Beck, Warszawa, s. 1054.

Weeks J. (1986) Sexuality, London, Travistock.

Węglarczyk G. (2009) Seksualność uczniów w świetle programów profilaktycznych realizowanych w szkołach w: Zachowania seksualne uczniów na terenie szkoły, M. Babik (red.), Kraków, Wydawnictwo WAM, s. 125-151.

Więcławska A. (2005) Nieletnie dziewczęta samotnie wychowujące dzieci a ich przygotowanie do radzenia sobie z ograniczeniami losu, Toruń, Wydawnictwo Uniwersytetu Mikołaja Kopernika, s. 215-240.

Włodarczyk E. (2008) Młodzież wobec macierzyństwa i jego kulturowej kreacji, Poznań, Wydawnictwo Naukowe UAM, s. 138-214.

Wróblewska W. (2006) Psychospołeczne i demograficzne następstwa wczesnej inicjacji seksualnej nastolatków, „Nowa Medycyna”, nr 4, s. 85-91.

Żelazkowska M. (2016) Wczesne macierzyństwo Kryzys czy szansa?, Olsztyn, Olsztyńska Szkoła Wyższa im. J. Rusieckiego w Olsztynie.

\section{Akty prawne}

Kodeks Cywilny, Dz.U. z 2018 r., poz. 1025.

Kodeks karny, Dz.U. z 2018 r., poz. 1600.

Kodeks rodzinny i opiekuńczy, Dz.U. z 2017 r., poz. 682.

Konstytucja Rzeczypospolitej Polskiej z dnia 2 kwietnia 1997 roku uchwalona przez Zgromadzenie Narodowe w dniu 2 kwietnia 1997 roku, przyjęta przez Naród w referendum konstytucyjnym w dniu 25 maja 1997 roku, podpisana przez Prezydenta Rzeczypospolitej Polskiej w dniu 16 lipca 1997 roku, Dz.U. z 1997 r., Nr 78, poz. 483.

Konwencja o prawach dziecka, przyjęta przez Zgromadzenie Ogólne Narodów Zjednoczonych dnia 20 listopada 1989 roku, Dz.U. z 1991 r., Nr 120, poz. 526.

Obwieszczenie Ministra Edukacji Narodowej z dnia 18 grudnia 2013 roku w sprawie ogłoszenia jednolitego tekstu rozporządzenia Ministra Edukacji Narodowej w sprawie sposobu nauczania szkolnego oraz zakresu treści dotyczących wiedzy o życiu seksualnym człowieka, o zasadach świadomego i odpowiedzialnego rodzicielstwa, 
o wartości rodziny, życia w fazie prenatalnej oraz metodach i środkach świadomej prokreacji zawartych w podstawie programowej kształcenia ogólnego, Dz.U. z 2014 r., poz. 395.

Rozporządzenie Ministra Edukacji Narodowej z dnia 27 sierpnia 2012 roku w sprawie podstawy programowej wychowania przedszkolnego oraz kształcenia ogólnego w poszczególnych typach szkół, Dz.U. z 2012 r., poz. 977.

Ustawa o planowaniu rodziny, ochronie płodu ludzkiego i warunkach dopuszczalności przerywania ciąży, Dz.U. z 1993 r., Nr 17, poz. 78.

Ustawa o postępowaniu w sprawach nieletnich, Dz.U. z 2018 r., poz. 969.

Ustawa o prawach pacjenta i Rzeczniku Praw Pacjenta, Dz.U. z 2017 r., poz. 1318.

\section{Źródła internetowe}

Biuro Regionalne WHO dla Europy i BZgA (2010) Standardy edukacji seksualnej w Europie. Podstawowe zalecenia dla decydentów oraz specjalistów zajmujących się edukacją i zdrowiem, https://www.bzga-whocc.de/fileadmin/user_upload/ Dokumente/WHO_BzgA_Standards_polnisch.pdf [dostęp: 1.08.2019].

Główny Urząd Statystyczny (2018) Rocznik Demograficzny

Główny Urząd Statystyczny, Urodzenia według wieku matki, (2018) http:// demografia.stat.gov.pl/bazademografia/Tables.aspx [dostęp: 1.08.2019].

Gradkowska A. (2018) Nieletnie matki i ich dzieci, https://mamywsparcie.pl/bazawiedzy/2018/8/31/nieletnie-matki-i-ich-dzieci [dostęp: 31.05.2019].

PONTON (2009) Jak naprawdę wygląda edukacja seksualna w polskich szkołach, http://ponton.org.pl/wp-content/uploads/2018/08/Raport2009.pdf [dostęp: 31.05.2019].

PONTON (2011) Jak wygląda edukacja w polskich domach. Raport http:// ponton.org.pl/wp-content/uploads/2018/09/Sk\%C4\%85d-wiesz-RAPORT_ostateczny. pdf [dostęp: 31.05.2019]

PONTON (2014) Sprawdzian z Wdż. Jak wygląda edukacja seksualna w polskich szkołach http://ponton.org.pl/wp-content/uploads/2018/09/raport_jaka_edukacja_2014_ 21112014.pdf [dostęp: 31.05.2019].

PONTON (2016) Realizacja zajęć WDŻ. Perspektywa uczennic/uczniów i dyrektorów/dyrektorek szkół http://ponton.org.pl/wp-content/uploads/2018/07/raport skrot_prawo_do_edukacji_seksualnej_ponton_2016.pdf [dostęp: 31.05.2019].

UNESCO (2009) International Technical Guidance on Sexuality Education http:// unesdoc.unesco.org/images/0018/001832/183281e.pdf [dostęp: 31.05.2019]. 